\title{
Efficacy of Insecticide against Girdle Beetle of Soybean, Glycine max (L.) Merril
}

\author{
Nikki Bhardwaj $^{1 *}$, S.B. Singh ${ }^{1}$ and Krishan Kumar Singh ${ }^{2}$
}

${ }^{1}$ Rajmata Vijayaraje Scindia Krishi Vishwavidyalaya, Gwalior, (M.P.), India

${ }^{2}$ School of Agriculture, Department of Horticulture, Career Point University,

Kota, Rajasthan, India

*Corresponding author

\section{A B S T R A C T}

Keywords

Insecticide, Girdle beetle, Soybean

Article Info

Accepted:

10 January 2018

Available Online:

10 February 2018
Efficacy of Quinalphos 25 EC, Chlorpyriphos 20 EC, Alphamethrin 10 EC was observed the overall maximum reduction in girdle beetle infestation was noticed in Quinalphos 25 EC (82.15\%) followed by Alphamethrin 10 EC (79.41\%), and it was minimum in Chlorpyriphos 20 EC (75.88\%). The highest grain yield (kg./ha.) was recorded in Quinalphos $25 \mathrm{EC}(950)$ and it was minimum in Chlorpyriphos $20 \mathrm{EC}(940)$. The best cost benefit ratio was noted in Quinalphos 25 EC (1:1.94) followed by Chlorpyriphos 20 EC (1:1.92)), and lowest in Alphamethrin 10 EC. (1:1.91).

\section{Introduction}

Soybean (Glycine $\max ($ L.) Merril) is known as the "Golden Bean" of the twentieth century.

Though soybean is a legume crop, yet it is widely used as oilseed. It can be grown on a variety of soil and in a wide range of climate. Soybean is a kharif crop in India, sown in June-July and harvested in late SeptemberOctober. Peak arrivals begin from October and November. It has emerged as an important commercial crop in many countries and international trade of soybean is spread globally.
Nationally it occupies an area of 110.65 lakh ha and its production is 69.29lakh MT. Madhya Pradesh ranks first in soybean production in India. Area and production of soybean in Madhya Pradesh are 56.12 lakh ha and 34.12 lakh MT, respectively (Sopa, 2015).

The major soybean producing states are Madhya Pradesh, Maharashtra, Rajasthan, Karnataka, Uttar Pradesh, Andhra Pradesh and Gujarat. It is a result of accumulating year in Soybean production, change in cropping practices, or global climate change, the distribution and impact of native and established pest is increasing in soybean. Soybean is affected by many species of insect pests (Aske et al., 2007). The populations of 
foliar insect pests including sucking pests and pod feeders such as bean leaf beetle, stink bugs and other pests, are increasing in many regions and efforts are being made to manage them. A number of insecticides have been tested earlier and exhibited effectiveness, but losses due to insect pests are still not below the economic injury level. It has been noticed that in last few years traditional insecticides are not in use due their resistance but after long interval their efficacy is again required to be tested. Chemical control strategies remain the main tool in the suppression of soybean defoliators. In the past, defoliators were controlled using broad spectrum insecticides such as Dimethoate $30 \mathrm{EC}$, Imidacloprid 17.8 SL, Trizophos 40 EC, Chlorpyriphos 20 EC, Alphamethrin 10 EC, Profenophos 50 EC, Quinalphos 25 EC,

The soybean defoliators mainly include tobacco caterpillar (Sopdoptera litura Fab.) and green semilooper (Chrysodeixis acuta). Immature stages (larva or caterpillar) of both tobacco caterpillar and green semilooper damages the crop at vegetative stage and in severe case, it completely defoliate the crop and dramatic yield loss. S. litura larvae even damages to soybean pods also (Sastawa et al., 2004). The control of pest in crop cost high to the famer. The study conducted in the year 2009, among soybean loopers, Chrysodeixis acuta and observed that these pests infested 1.7 million acres of soybeans and caused a 19 $\%$ total loss plus cost of control to producers (Musser, and Catchot, 2009). Chemical control strategies remain the main tool in the suppression of soybean insect pest. In the past, defoliators were controlled using broad spectrum insecticides such as organochlorins, organophosphates, synthetic pyrathroids and carbamates. Overuse and reliance on these insecticides led to many documented cases of resistance of virtually all classes of insecticides (Brewer et al., 1990 and Wolfenbarger and Brewer, 1993). Today, insecticides applications are mainly limited to lepidopteran- specific compounds and newer chemistries of insecticides such as diamides. Presently the insecticides recommended for the control of defoliators are methomyl (carbamate), indoxacarb (oxadiazine), spinosad (spinosyn) and flubendiamide (diamide). It is known fact that these both lepidopteron defoliators showed certain levels of behavioral resistance to different class of insecticides, hence successful control of this pest is some extent difficult. Keeping this in view, study was under taken to test the effectiveness of some newer group of molecules against these pest in soybean.

\section{Materials and Methods}

The trials were laid out during the year 201516 in a randomized block design having plot size of $5 \times 2.7 \mathrm{~m}^{2}$ at, experimental farm. The cultivar RVS 2001-4 was sown on 27 June 2015 with all the recommended agronomical practices were followed by College of Agriculture, Indore except insect pest management. Different treatments comprising of seven insecticides, as per the details given in the Table 1 were applied with the help of manually operated hand knapsack sprayer.

Observations on larval population and percent pod damage were recorded procedure given by (Harish, 2008). Three randomly spots of one square meter row in each treatment leaving border rows. Larval count was made by shaking the plant gently over a white cloth placed between the rows. Average number of caterpillars found per square meter row was worked out for pre count 3,7 and 14 days after Spraying For percent pod damage, ten plants are randomly selected from each plot and total number of pods and damaged pods at the time of harvesting were recorded and mean was calculated. Percent pod damage was calculated by following formula.

Percent pod damage $=\frac{\text { Number of damaged pods }}{\text { Total no. of pod }} \times 100$ 
At the time of harvesting, yield from each plot was taken separately and converted into $\mathrm{kg} / \mathrm{ha}$ and statistically analyzed. Data obtained were subjected to analysis of variance (ANOVA) after transformation of data through CPCS-I software and as per the procedure suggested by Gomez and Gomez (1984).

\section{Results and Discussion}

It was observed that soybean crop was heavily attacked by soybean insect and defoliators during the season. Results of the present investigation, Efficacy of insecticide against insect pest of soybean, Glycine Max (L.) Merril are elucidated here. There were significant differences among the treatments applied for the soybean insects.

\section{Effect of treatments on girdle beetle infestation}

The overall reduction in girdle beetle population after three applications of treatments over pre-treatment population of first application to the last count of third spray was calculated (Table 2). The result revealed that the maximum reduction in population was noticed in quinalphos 25 EC $(82.15 \%)$ followed by alphamethrin 10 EC (79.41\%), trizophos 40EC (78.37\%), imidacloprid 17.8 SL (78.61\%), dimethoate $30 \mathrm{EC}(77.41 \%)$ and profenphos 50 EC $(77.18 \%)$ and it was minimum in chlorpyriphos 20EC (75.88\%). Kalyan and Ameta (2016) studied two sprays given in the soybean, of which first spray was given against semilooper and girdle beetle at 35 days after germination (DAG) and second spray was given at 55 DAG against gram pod borer and tobacco caterpillar. It was followed by imidacloprid $200 \mathrm{SL}$, while the significant highest reduction in the larval population of semilooper and girdle beetle was recorded in case of Profenophos $50 \mathrm{EC}$ at 3 and 5 (DAS). It was followed by triazophos $40 \mathrm{EC}$ and dimethoate 30 EC against semilooper and girdle beetle, respectively. Similar trends were also observed at 7 DAS.

\section{Cost benefit ratio}

\section{Grain yield (kg/ha)}

Data pertaining to yield and economics were presented in Table 3. The highest grain yield (kg./ha.) was recorded in chlorpyriphos $20 \mathrm{EC}$ (950)) and differed significantly with all the treatments. The next best treatment was quinolphos 25 EC (850) which also showed significant difference with remaining treatments. The third best treatment was observed as alphamethrin 10 EC (920). Khandwe and Waghmare (2003) reported that two sprays given of chlorpyriphos at 40 and 45 DAS gave the highest yield (18.24 q/ha) and (Rs. 412/ha) of soybean.

\section{Cost benefit ratio}

The best cost benefit ratio was noted in Quinalphos 25 EC (1:1.94) followed by Chlorpyriphos 20 EC $(1: 1.92))$, and lowest in Alphamethrin 10 EC. (1:1.91). In a study carried out by Kalyan and Ameta 2016 \& recorded cost benefit ratio. Insecticidal spray schedule was comprising of first spray of triazophos 40 EC @ 1.25 1/ha at 35 DAG followed by second spray of flubendiamide 480 SC @ 100 ml/ha at 55 DAG provided the highest mean seed yield of $1925 \mathrm{~kg} / \mathrm{ha}$. The maximum net profit of Rs. 15, 008/ha was obtained in case of spray schedule comprising first spray of triazophos 40 EC @ 1.25 1/ha at 35 DAG followed by second spray of flubendiamide $480 \mathrm{SC} @ 100 \mathrm{~g} / \mathrm{ha}$ at $55 \mathrm{DAG}$ with the maximum cost: benefit ratio of 1 : 8.52. The minimum net profit of Rs. 3, 698/ha was obtained in first spray of monocrotophos 36 SL followed by second spray of triazophos $40 \mathrm{EC}$ with the minimum cost: benefit ratio of 1: 3.32 . 
Table.1 Detail of different treatments

\begin{tabular}{|c|c|c|c|c|c|c|}
\hline Treatment & Name of insecticides & Tread name & Recommended concentration (\%) & Class & Mode of action & Dose g.a.i./ha \\
\hline T1 & Quinolphos 25EC & Ekalux AF & 0.05 & Organophosphate & Contact \& Stomach & 250 \\
\hline $\mathbf{T} 2$ & Chlorpyriphos 20EC & Dursban & 0.06 & Organophosphate & Stomach action & 300 \\
\hline T3 & Alphamethrin 10EC & Guru & 0.003 & Synthetic Pyrithroid & Contact \& Stomach & 15 \\
\hline T4 & Control & - & - & - & - & - \\
\hline
\end{tabular}

* Figures in the parenthesis are angular transformed values.

Table.2 Effect of different insecticide on soybean girdle beetle (pooled data of 2015-16)

\begin{tabular}{|c|c|c|c|c|c|c|c|c|c|c|c|}
\hline \multirow[t]{2}{*}{ Treatment } & \multirow{2}{*}{$\begin{array}{c}\text { Doses } \\
\text { g.a.i. ha-1 }\end{array}$} & \multirow{2}{*}{$\begin{array}{c}\text { Pre- } \\
\text { treatment } \\
\text { count }\end{array}$} & \multicolumn{3}{|c|}{ After $1^{\text {st }}$ spray } & \multicolumn{3}{|c|}{ After $2^{\text {st }}$ spray } & \multicolumn{3}{|c|}{ After $3^{\text {st }}$ spray } \\
\hline & & & 3 DAS & 7 DAS & 14 DAS & 3 DAS & 7 DAS & 14 DAS & 3 DAS & 7 DAS & 14 DAS \\
\hline $\begin{array}{l}\text { Quinolphos } \\
\text { 25EC }\end{array}$ & 250 & $\begin{array}{c}10.86 \\
(19.21)\end{array}$ & $\begin{array}{c}6.22 \\
(14.44)\end{array}$ & $\begin{array}{c}6.33 \\
(14.57)\end{array}$ & $\begin{array}{c}6.43 \\
(14.68)\end{array}$ & $\begin{array}{c}4.64 \\
(12.38)\end{array}$ & $\begin{array}{c}4.79 \\
(12.62)\end{array}$ & $\begin{array}{c}4.86 \\
(12.71)\end{array}$ & $\begin{array}{c}2.68 \\
(9.41)\end{array}$ & $\begin{array}{c}2.73 \\
(9.51)\end{array}$ & $\begin{array}{c}2.82 \\
(9.66)\end{array}$ \\
\hline $\begin{array}{c}\text { Imidacloprid } \\
\text { 17.8SL }\end{array}$ & 19.93 & $\begin{array}{l}9.731 \\
(8.00)\end{array}$ & $\begin{array}{c}5.86 \\
(13.96)\end{array}$ & $\begin{array}{c}6.05 \\
(14.22)\end{array}$ & $\begin{array}{c}6.14 \\
(14.33)\end{array}$ & $\begin{array}{c}3.73 \\
(11.11)\end{array}$ & $\begin{array}{c}3.87 \\
(11.32)\end{array}$ & $\begin{array}{c}3.97 \\
(11.47)\end{array}$ & $\begin{array}{c}2.13 \\
(8.39)\end{array}$ & $\begin{array}{c}2.23 \\
(8.59)\end{array}$ & $\begin{array}{c}2.31 \\
(8.72)\end{array}$ \\
\hline $\begin{array}{c}\text { Trizophos } \\
\text { 40EC }\end{array}$ & 300 & $\begin{array}{c}10.84 \\
(19.19)\end{array}$ & $\begin{array}{c}6.29 \\
(14.48)\end{array}$ & $\begin{array}{c}6.38 \\
(14.60)\end{array}$ & $\begin{array}{c}6.44 \\
(14.67)\end{array}$ & $\begin{array}{c}4.50 \\
(12.24)\end{array}$ & $\begin{array}{c}4.76 \\
(12.60)\end{array}$ & $\begin{array}{c}4.83 \\
(12.69)\end{array}$ & $\begin{array}{c}2.85 \\
(9.70)\end{array}$ & $\begin{array}{c}2.91 \\
(9.81)\end{array}$ & $\begin{array}{c}3.00 \\
(9.96)\end{array}$ \\
\hline $\begin{array}{c}\text { Chlorpyriphos } \\
\text { 20EC }\end{array}$ & 300 & $\begin{array}{c}11.57 \\
(19.87)\end{array}$ & $\begin{array}{c}7.46 \\
(15.82)\end{array}$ & $\begin{array}{c}7.51 \\
(15.87)\end{array}$ & $\begin{array}{c}7.58 \\
(15.96)\end{array}$ & $\begin{array}{c}4.74 \\
(12.54)\end{array}$ & $\begin{array}{c}4.98 \\
(12.88)\end{array}$ & $\begin{array}{c}5.05 \\
(12.97)\end{array}$ & $\begin{array}{c}3.15 \\
(10.17)\end{array}$ & $\begin{array}{c}3.23 \\
(10.31)\end{array}$ & $\begin{array}{c}3.35 \\
(10.51)\end{array}$ \\
\hline $\begin{array}{l}\text { Alphamethrin } \\
\text { 10EC }\end{array}$ & 15 & $\begin{array}{c}10.64 \\
(18.99)\end{array}$ & $\begin{array}{c}6.88 \\
(15.20)\end{array}$ & $\begin{array}{c}6.95 \\
(15.28)\end{array}$ & $\begin{array}{c}7.05 \\
(15.38)\end{array}$ & $\begin{array}{c}5.63 \\
(13.69)\end{array}$ & $\begin{array}{c}5.77 \\
(13.86)\end{array}$ & $\begin{array}{c}5.86 \\
(13.98)\end{array}$ & $\begin{array}{c}3.89 \\
(11.33)\end{array}$ & $\begin{array}{c}3.98 \\
(11.47)\end{array}$ & $\begin{array}{c}4.05 \\
(11.59)\end{array}$ \\
\hline $\begin{array}{c}\text { Prophenophos } \\
\text { 50EC }\end{array}$ & 250 & $\begin{array}{c}10.49 \\
(18.87)\end{array}$ & $\begin{array}{c}6.03 \\
(14.21)\end{array}$ & $\begin{array}{c}6.16 \\
(14.36)\end{array}$ & $\begin{array}{c}6.35 \\
(14.60)\end{array}$ & $\begin{array}{c}3.82 \\
(11.25)\end{array}$ & $\begin{array}{c}3.92 \\
(11.39)\end{array}$ & $\begin{array}{c}4.04 \\
(11.55)\end{array}$ & $\begin{array}{c}2.75 \\
(9.52)\end{array}$ & $\begin{array}{c}2.95 \\
(9.84)\end{array}$ & $\begin{array}{c}3.06 \\
(10.04)\end{array}$ \\
\hline $\begin{array}{c}\text { Dimethoate } \\
\text { 30EC }\end{array}$ & 300 & $\begin{array}{c}11.27 \\
(19.60)\end{array}$ & $\begin{array}{c}7.85 \\
(16.24)\end{array}$ & $\begin{array}{c}7.97 \\
(16.36)\end{array}$ & $\begin{array}{c}8.05 \\
(16.46)\end{array}$ & $\begin{array}{c}4.47 \\
(12.21)\end{array}$ & $\begin{array}{c}4.56 \\
(12.32)\end{array}$ & $\begin{array}{c}4.68 \\
(12.49)\end{array}$ & $\begin{array}{c}2.77 \\
(9.56)\end{array}$ & $\begin{array}{c}2.94 \\
(9.83)\end{array}$ & $\begin{array}{c}3.27 \\
(10.37)\end{array}$ \\
\hline \multirow[t]{3}{*}{ Control } & - & $\begin{array}{c}14.34 \\
(22.24)\end{array}$ & $\begin{array}{c}14.24 \\
(22.17)\end{array}$ & $\begin{array}{c}14.30 \\
(22.21)\end{array}$ & $\begin{array}{c}14.30 \\
(22.21)\end{array}$ & $\begin{array}{c}14.23 \\
(22.16)\end{array}$ & $\begin{array}{c}14.17 \\
(22.10)\end{array}$ & $\begin{array}{c}14.26 \\
(22.18)\end{array}$ & $\begin{array}{c}14.33 \\
(22.24)\end{array}$ & $\begin{array}{c}14.25 \\
(22.17)\end{array}$ & $\begin{array}{c}14.20 \\
(22.13)\end{array}$ \\
\hline & & 8.42 & 6.99 & 6.03 & 5.11 & 6.90 & 6.47 & 6.41 & 7.67 & 8.11 & 8.20 \\
\hline & & NS & 0.88 & 0.91 & 0.91 & 0.92 & 0.94 & 0.95 & 0.49 & 0.52 & 0.56 \\
\hline
\end{tabular}

* Figures in the parenthesis are angular transformed values. 
Table.3 Effect of different insecticide on soybean yield and cost economics (pooled data of 2015-16)

\begin{tabular}{|c|c|c|c|c|c|c|c|c|c|}
\hline Treatments & $\begin{array}{c}\text { Cost of } \\
\text { cultivatio } \\
\text { n (Rs/ha) }\end{array}$ & $\begin{array}{l}\text { Quantity of } \\
\text { insecticide used } \\
\text { for } 3 \text { sprays } \\
(\mathrm{ml} \text { or } \mathrm{gm} / \mathrm{ha})\end{array}$ & $\begin{array}{c}\text { Cost of } \\
\text { Insecticides } \\
\left(\operatorname{Rs~ha}^{-1}\right)\end{array}$ & $\begin{array}{c}\text { Labour cost } \\
2 \text { labourers } \\
\text { per spray per } \\
\text { ha }\end{array}$ & $\begin{array}{c}\text { Total } \\
\text { cost }(\mathrm{Rs})\end{array}$ & $\begin{array}{l}\text { Yield } \\
\mathrm{kg} / \mathrm{ha}\end{array}$ & $\begin{array}{c}\text { Gross } \\
\text { income } \\
(\mathbf{R s})\end{array}$ & $\begin{array}{c}\text { Net } \\
\text { income } \\
(\mathbf{R s})\end{array}$ & $\begin{array}{l}\text { Cost } \\
\text { benefi } \\
\text { t ratio }\end{array}$ \\
\hline T1- Quinolphos 25 EC & 17500 & 3000 & 675 & 1200 & 19375 & 850 & 34000 & 16500 & $1: 1.75$ \\
\hline T2-Imidacloprid1 7.8 SL & 17500 & 336 & 344 & 1200 & 19044 & 1500 & 60000 & 40956 & $1: 3.15$ \\
\hline T3 - Trizophos 40 EC & 17500 & 2250 & 1008 & 1200 & 19708 & 1400 & 56000 & 36292 & $1: 2.84$ \\
\hline T4 - Chlorpyriphos 20 EC & 17500 & 4500 & 1126 & 1200 & 19826 & 950 & 38000 & 18174 & $1: 1.91$ \\
\hline T5- Alphamethrin 10 EC & 17500 & 450 & 202 & 1200 & 18902 & 920 & 36800 & 17898 & $1: 1.94$ \\
\hline T6 -Profenophos 50 EC & 17500 & 1500 & 862 & 1200 & 19562 & 870 & 34800 & 15238 & $1: 1.77$ \\
\hline T7 - Dimethoate 30 EC & 17500 & 3000 & 2174 & 1200 & 20874 & 910 & 36400 & 15526 & $1: 1.74$ \\
\hline T8 - Untreated check & 17500 & ----- & & 1200 & 18700 & 540 & 21600 & 2900 & -- \\
\hline CD at $5 \%$ & - & - & - & - & - & 39.96 & - & - & - \\
\hline
\end{tabular}


The overall reduction in girdle beetle population after three applications of treatments over pre-treatment population of first application to the last count of third spray was calculated. The result revealed that the maximum reduction in population was noticed in quinalphos 25 EC $(82.15 \%)$ followed by alphamethrin $10 \mathrm{EC}(79.41 \%)$, trizophos 40 EC (78.37\%), imidacloprid 17.8 SL $(78.61 \%)$, dimethoate $30 \mathrm{EC}(77.41 \%)$ and profenophos $50 \mathrm{EC}(77.18 \%)$ and it was minimum in chlorpyriphos $20 \mathrm{EC}(75.88 \%)$.

\section{References}

Anonymous, (2014). Estimates of area, productivity $\&$ production of soybean in India during Kharif. The soybean processors association of India. PP.1-4.

Aske S., Khandwe N. and Singh K.J. (2007). Incidence and damage of major pest of soybean in Madhya Pradesh. Insect Environ. 12 (4):156-159.

Brewer, M. J., Trumble, J. T., AlvaradoRodriguez, B. and Chaney, W. E. (1990) Beet army worm (Lepidoptera: Noctuidae) adult and larval susceptibility to three insecticides in managed habits and relationship to laboratory selection for resistance Journal of Economic Entomology. 83(6): 813-814.

Harish, G. 2008. Studies on incidence and management of defoliator pests of soybean M. Sc., (Agri) thesis submitted to University of Agricultural Sciences Dharwad. Pp. 65.

Kalyan R. K., Ameta O. P. (2016) Efficacy of various insecticidal spray schedules against insect pests of soybean. Indian j., 17(1):137-143.

Khandwe N. Waghmare S.K. (2003). Chemical control of green semiloopers, Chrysodeixis acuta (Walker) and Plusia orichalsia (Fabricius) in soybean. JNKVV Res. J. 37 (2): 108-111.

Musser, F. R. and Catchot, A. (2009). Soybean Insect Losses for Mississippi, Tennessee and Arkansas. Midsouth. Ento. 3: 9-36.

Sastawa, B. M., Lawan, M. and Maina, Y. T. (2004). Management of insect pests of soybean. Effects of sowing dates and intercropping on damage and grain yield in the Nigerian Sudan Savanna. Crop Prot. 23(2): 155-161.

Sopa, (2015). All data collect from www.sopa.org.

Wolfenbarger, D. A. and Brewer, M. J. (1993) Toxicity of selected pesticides to field collected beet armyworm populations. In Proceedings, $46^{\text {th }}$ Beltwide cotton insect research and control conference. National Cotton Council, Memphis, TN. p. 1174.

\section{How to cite this article:}

Nikki Bhardwaj, S.B. Singh and Krishan Kumar Singh. 2018. Efficacy of Insecticide against Girdle Beetle of Soybean, Glycine max (L.) Merril. Int.J.Curr.Microbiol.App.Sci. 7(02): 905910. doi: https://doi.org/10.20546/ijcmas.2018.702.114 